\title{
Microscopic Anatomy of the Lining of Hemal Spaces in the Penaeid Shrimp, Sicyonia ingentis
}

\author{
Rachel Brittany Sidebottom, Sabi Bang (1) and Gary Martin* \\ Department of Biology, Occidental College, Los Angeles, CA 90041, USA; rsidebottom@oxy.edu (R.B.S.); \\ sbang2@oxy.edu (S.B.) \\ * Correspondence: gmartin@oxy.edu; Tel.: +1-323-259-2890
}

Citation: Sidebottom, R.B.; Bang, S.; Martin, G. Microscopic Anatomy of the Lining of Hemal Spaces in the Penaeid Shrimp, Sicyonia ingentis. J. Mar. Sci. Eng. 2021, 9, 862. https:// doi.org/10.3390/jmse9080862

Academic Editor: Qi Li

Received: 8 June 2021

Accepted: 9 August 2021

Published: 11 August 2021

Publisher's Note: MDPI stays neutral with regard to jurisdictional claims in published maps and institutional affiliations.

Copyright: (c) 2021 by the authors. Licensee MDPI, Basel, Switzerland. This article is an open access article distributed under the terms and conditions of the Creative Commons Attribution (CC BY) license (https:// creativecommons.org/licenses/by/ $4.0 /)$.

\begin{abstract}
The purpose of this paper is to present a morphological description of three different types of acellular material lining hemal spaces in a shrimp, providing a background for addressing future questions. The vasculature of the penaeid shrimp, Sicyonia ingentis, includes vessels leading from the heart into arteries which branch and expand into sinuses before returning hemolymph back to the heart. Early work showed that an endothelium was absent, and a basement membrane (BM) separated tissues from the hemolymph. Therefore, it was suggested that hemocytes could identify anything other than the BM as a "foreign" entity. This study demonstrates three major types of acellular material lining the hemal spaces of S. ingentis. Cardiomyocytes, digestive gland tubules, and abdominal muscle fibers are covered by BMs. Major arteries are lined by a fibrillin-like fibrous material. Finally, sheaths of collagenous connective tissues cover the heart and digestive gland as well as the outer surface of arteries, the gut, and gonad. Our understanding of hemocyte receptors and extracellular matrices in general have greatly expanded but the biochemical composition of the matrices lining crustacean hemal spaces, their role in regulating nutrient uptake, and the cells responsible for their deposition deserve further attention.
\end{abstract}

Keywords: crustacean; vasculature; extracellular matrix; basement membrane; connective tissue sheath; fibrillin

\section{Introduction}

Decapod crustaceans have a "semi-open" [1] or "incompletely closed" [2] circulatory system, meaning that hemolymph is not completely contained within vessels as it travels throughout the body. Although arteries extend from the heart and branch into smaller tubes, the vessels eventually end and expand into sinuses before the hemolymph drains back into the heart; veins are absent $[1,3]$. Shrimp hemal spaces lack an endothelium and instead are lined by an extracellular matrix [4]. Circulating fluid is called hemolymph because there is no separation of blood from lymph, and it bathes the surfaces of tissues and organs directly [2].

In 1970, it was suggested that circulating hemocytes (blood cells) might identify non-self materials as anything differing from the matrix lining hemal spaces, which was called a basement membrane (BM) [5]. In 1984, the idea was expanded to suggest that hemocytes moving past these surfaces receive signals regarding the presence of foreign materials [6]. Our understanding of the repertoire of receptors on hemocytes has greatly expanded with continued research on invertebrate innate immunity and now includes toll-like receptors [7,8], integrins [9-11], lectins [12], and pattern-recognition motifs [13].

Our understanding of BMs and extracellular matrices has also greatly expanded mostly in vertebrate systems, while knowledge on the extracellular matrices lining hemal spaces in crustaceans has received little attention. Typically, the morphology of these primarily acellular layers is only noted in passing in descriptions focusing on the cellular components of particular tissues [14-17], only a single type of matrix has been described 
in each study, and a variety of terms have been used such as BMs, basal laminae, internal/external laminae, and tunica intimae.

This paper will demonstrate that three types of acellular materials line hemal spaces in different regions of the penaeid shrimp Sicyonia ingentis: BMs, elastic fibrillin-like layers, and connective tissue sheaths. The first type of acellular material, basement membranes, has been well studied in vertebrates where they provide mechanical support to epithelial cells [18-20] while influencing macromolecule exchange between blood and tissues [19]. There are considerable morphological variations seen in invertebrates [21] and the use of the term basement membrane was encouraged "as a general descriptive and comprehensive word to be used in light microscopy, biochemistry and electron microscopy". At the light microscope level, BMs appear as thin layers separating epithelia from underlying connective tissue and stain positive with PAS. At the TEM level, three layers may be seen; an electron-lucent lamina rara beneath the plasma membrane followed by the lamina densa and a second electron-lucent zone called the lamina reticularis, which blends into the underlying connective tissue when present [21]. The major component of BMs is collagen type IV, localized within the lamina densa [18,21-24].

An important difference between BMs in vertebrate vessels and the ones lining crustacean (as well as most other invertebrates) hemal spaces is that in the latter the BM faces an epithelium on one side and a hemal space on the other. In vertebrate vessels, a BMs lies between the basal surface of the endothelium and the underlying connective or muscular tissues. In both vertebrates and invertebrates, BMs also surround specialized cells such as adipose cells and striated and cardiac muscle cells [25-31].

A second type of matrix is restricted to the inner lining of large arteries extending from the heart in shrimp [17], lobsters [32], and crab [33]. It has been called the tunica interna (internal lamina) [4,17], it is thicker than a BM, and is composed of a weave of microfibrils. In the shrimp, it stains with histological dyes for elastin [17], but not so in the crab [33]. Work on lobsters has demonstrated it reacts with antibodies to mammalian fibrillin [32,34,35], a glycoprotein involved with the deposition of tropoelastin during the formation of elastic fibers [36-38]. The fibrils themselves have elastic properties in the lobster artery and assist in propagation of blood following contraction of the heart [32].

The third acellular matrix lining hemal spaces is a connective tissue sheath which has been described as "fundamentally an accumulation of collagen fibrils" [39]. In that study, the term tunica externa was used, and it was noted that the layers of collagen are oriented primarily longitudinally to blood flow with sparse, interspersed fibroblast-like cells. The fibrils surround the outer surfaces of blood vessels and the gut (fore-, mid-, and hind-gut), as well as forming sheaths surrounding the entire collection of digestive gland tubules [40], and nerves [41-44].

The goal of this study is to make these linings the focus of a morphological description presenting the diversity of these matrices past which hemocytes and hemolymph circulate within a single crustacean, the penaeid shrimp Sicyonia ingentis. This will set the stage for future work to characterize the biochemical nature of these layers and their roles in nutrient exchange.

\section{Materials and Methods}

\subsection{Collection and Maintenance of Shrimp}

Adult, sexually mature ridgeback prawns, Sicyonia ingentis, were collected in $100 \mathrm{~m}$ of water off the coast of Palos Verdes, California by otter trawls in April 2019. Shrimp averaged $14.5 \pm 3.3 \mathrm{~g}$ and were in molt stage D [45]. The shrimp were kept in aquaria with salt-water at $15^{\circ} \mathrm{C}$ and 33 ppt salinity.

\subsection{Tissue Collection and Processing}

The stomach, digestive gland (outer covering of entire organ as well as individual tubules), midgut trunk, gonad, heart, dorsal abdominal artery, and muscle from the dorsal 
wall of the 4th abdominal segment were carefully removed from the body of the shrimp and immersed in fixatives (see below).

For light microscopy (LM), tissues and organs were cut into pieces $1 \mathrm{~cm}^{3}$ and fixed for a minimum of $3 \mathrm{~h}$ in half-strength Karnovsky's fixative ( $2 \%$ formaldehyde, $2.5 \%$ glutaraldehyde in $0.1 \mathrm{M}$ sodium cacodylate $\mathrm{pH}$ 7.4) and processed for standard paraffin embedding. Thick sections $(8 \mu \mathrm{m})$ were stained with hematoxylin and eosin, periodic acid-Schiff procedure (Sigma-Aldrich, St. Louis, MO, USA; kit 395B), and Masson's trichrome stain (Sigma-Aldrich St. Louis, MO, USA; kit HT15), using standard procedures [46].

For scanning electron microscopy (SEM), similar sized pieces of tissues and organs were cut adjacent to those selected for LM and fixed in 3\% glutaraldehyde in $0.1 \mathrm{M}$ sodium cacodylate $\mathrm{pH} 7.4$ containing $12 \%$ glucose for $3 \mathrm{~h}$. Samples were then dehydrated in a graded series of ethanol, dried using hexamethyldisilane (Pella 18605), coated with gold in a Technics Hummer 2, and examined in a Phenom SEM.

For transmission electron microscopy (TEM), tissues were fixed overnight in the same fixative used for SEM, washed $10 \mathrm{~min}$ in buffer ( $0.1 \mathrm{M}$ sodium cacodylate with $24 \%$ sucrose), post-fixed $1 \mathrm{~h}$ in $1 \% \mathrm{OsO}_{4}$ in $0.1 \mathrm{M}$ sodium cacodylate buffer, stained en bloc for $1 \mathrm{~h}$ in $3 \%$ uranyl acetate in $0.1 \mathrm{M}$ sodium acetate buffer $\mathrm{pH} 4.5$, dehydrated through a series of ethanol, and infiltrated and embedded in Spurr's plastic [47]. Semi-thin sections $(0.5 \mu \mathrm{m})$ were stained with methylene blue and thin sections $(70 \mathrm{~nm})$ were stained with lead citrate and viewed in a Zeiss Laborlux 12 light microscope and a Zeiss EM 109 transmission electron microscope (TEM), respectively.

\subsection{Measurements}

Ten shrimp were examined in this study; five were processed for paraffin embedding and examination by LM, five were processed for TEM and SEM. For LM and TEM, one block from each sample was examined to produce ten images used for measurements. For SEM, three measurements were made on a sample from each tissue. Measurements reported in the text are presented as the range, and the mean \pm one standard deviation.

\section{Results}

\subsection{Distribution of Hemal Spaces}

Blood is pumped from the heart into several large arteries that branch into narrower vessels, which eventually end such that the hemolymph flows into spaces around and directly bathes tissues and organs (Figure 1). The linings of the major vessels and the external surfaces of the tissues and organs are described below.

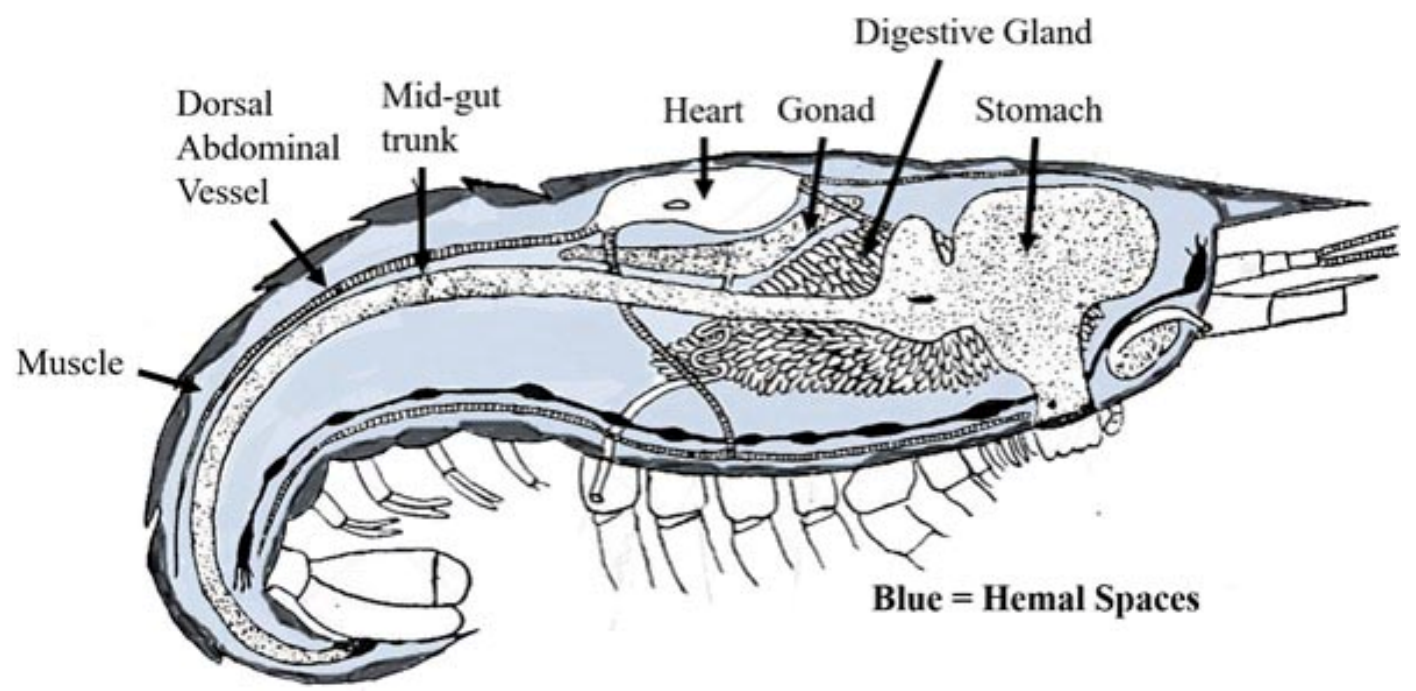

Figure 1. Schematic of shrimp anatomy displaying organs adjacent to hemal spaces. Blood also fills the heart and dorsal abdominal artery and surrounds individual tubules within the digestive gland. 


\subsection{Fibrillin-like Lining of Major Arteries}

The wall of the dorsal abdominal artery measures between $50.2-65.5,(\bar{x}=58.2 \pm 0.8)$ $\mu \mathrm{m}$ thick and is composed of the following layers (Figure 2A); an innermost fibrillin-like layer, a thin layer of muscle $(6.4-9.7,(\bar{x}=7.3 \pm 0.6 \mu \mathrm{m})$, two additional fibrillin layers $(4.0-10.4 \pm 0.5 \mu \mathrm{m})$ separated by loose connective tissue $(10.4-12.2,(\bar{x}=11.6 \pm 0.8 \mu \mathrm{m})$ and an outer bounding connective tissue sheath (see Section 3.4). The inner fibrillin lining

(Figure 2A) is thin $(1.0-1.5,(\bar{x}=1.2 \pm 0.3 \mu \mathrm{m})$ and stains with eosin and PAS but does not stain with trichrome for collagen. When viewed by SEM (Figure 2B,C) the surface is smooth with folds ranging in width between $16.6 \mu \mathrm{m}$ and $23.2 \mu \mathrm{m}$, which may be due to shrinkage or contraction during processing. At higher magnification (Figure 2C), the smooth surface presents low profile ridges $(0.4 \mu \mathrm{m}$ in width) running primarily parallel to the long axis of the vessel. The ridges have the same diameter as pseudopodal extensions from attached hemocytes and may represent remnants of detached cells or exposed filaments that make up the inner layer of the vessel wall. When examined using TEM, the inner fibrillin layer is composed of fibrils (22.2-29.8, $\bar{x}=26.4 \pm 1.4$ nm diameter) forming a meshwork (Figure 2D).
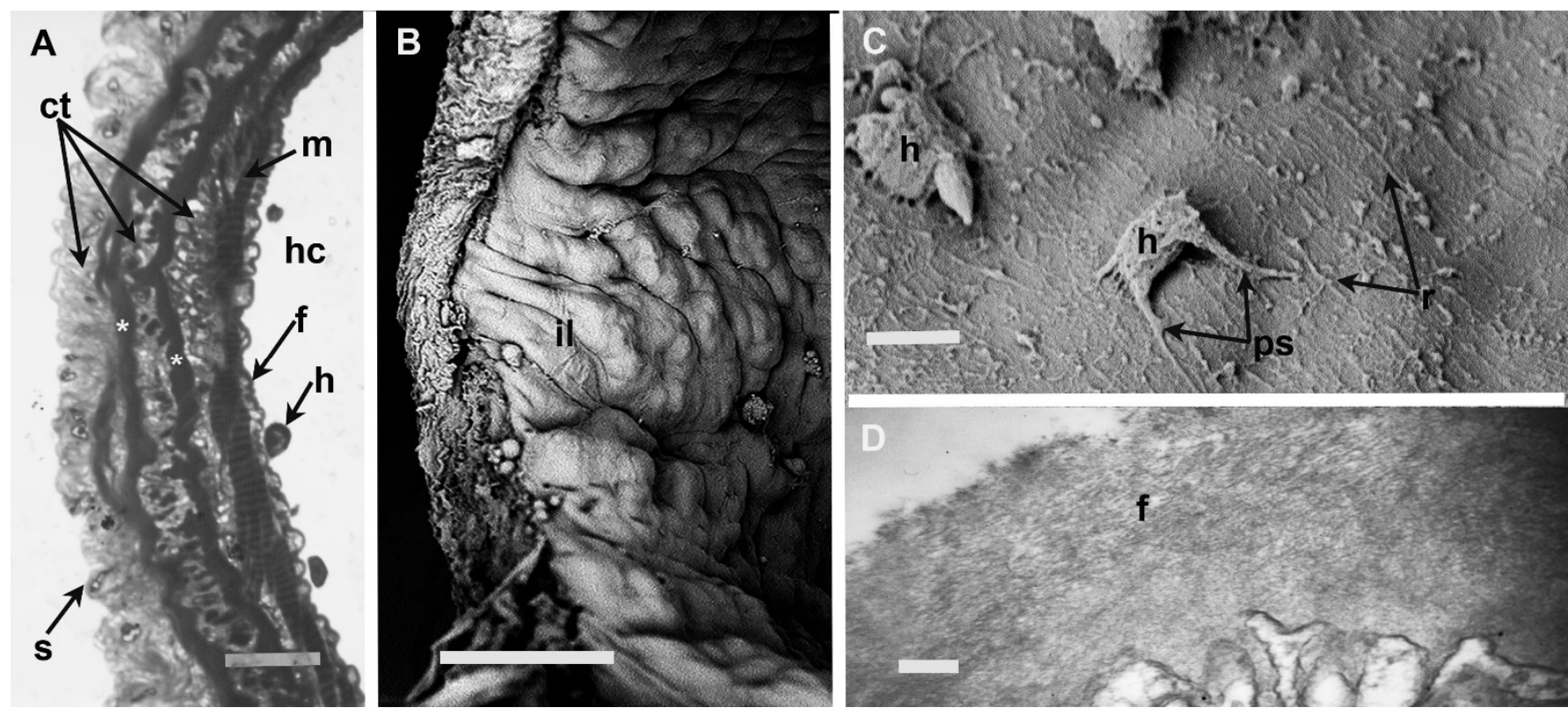

Figure 2. Inner lining of the dorsal abdominal artery. (A) Light micrograph of cross section through vessel wall showing inner lining of fibrillin-like material (f) separating the hemocoel (hc) and a hemocyte (h) from three wall layers of connective tissue (ct), separated by two additional layers of fibrillin $\left(^{*}\right)$, each outside of a muscle layer (m). An outer connective tissue sheath (s) surrounds the entire vessel. (B) Low magnification view of inner vessel lining (il) showing folded surface. (C) Higher magnification view of inner fibrillin surface and attached hemocytes (h) with extended pseudopodia (ps) tapering to diameters like small ridges (r) running parallel to long axis of vessel. (D) Transmission electron micrograph showing the weave of filaments in the fibrillin layer (f) covering a ridge on the surface. Scale bar (A) $50 \mu \mathrm{m},(\mathbf{B}) 50 \mu \mathrm{m},($ C) $10 \mu \mathrm{m}$, (D) $0.25 \mu \mathrm{m}$.

\subsection{Tissues Lined by $B M$}

Individual heart myocytes, tubules of the digestive gland, and abdominal muscle fibers are separated from hemal spaces by BMs too thin to be resolved clearly at the LM level. All stain positive with PAS and faintly with eosin and trichrome. SEM of cardiac myocytes shows a surface with longitudinal folds as well as periodic constrictions every $4.5-9.0 \mu \mathrm{m}$, the latter possibly due to contraction during processing (Figure 3A). At higher magnification, the BM seen between constrictions is smooth with widely spaced and 
randomly oriented filaments $(0.3-0.7, \bar{x}=0.5 \pm 0.2 \mu \mathrm{m}$ diameter). Hemocytes were commonly seen bound to the surface either singularly or in clusters of two to four hemocytes (7.2-8.5 $\mu$ m diameter; Figure 3B).
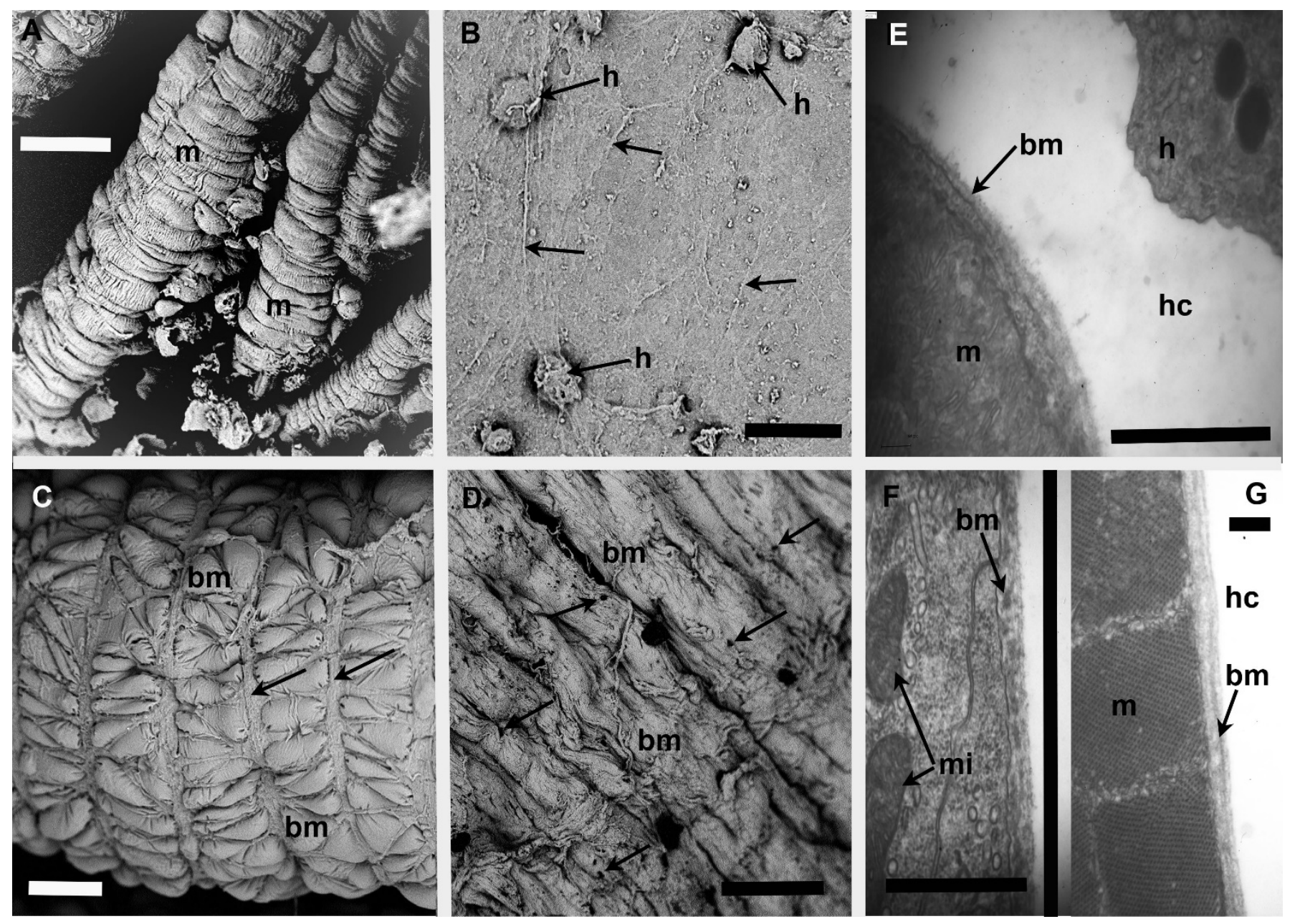

Figure 3. Tissues encased within basement membranes. (A) Scanning electron micrograph (SEM) of individual contracted cardiac myocytes (m). (B) Higher magnification SEM showing BM surrounding myocytes (which is the same as seen covering individual digestive gland tubules and abdominal muscle fibers) with attached hemocytes (h) and fine ridges (arrows). (C) Low magnification SEM of surface of individual tubule from digestive gland with basement membrane (bm) constricted periodically by thicker circumferentially arranged contractile cells (arrows) and thin cells running longitudinally causing the BM to form bulges. (D) SEM showing surface of adjacent fibers from abdominal muscle covered by a basement membrane (bm). An occasional collagen fiber and small pores (arrows) are seen on the surface. (E) Transmission electron micrograph (TEM) showing thin basement membrane (bm) covering a myocyte $(\mathrm{m})$ and the edge of hemocyte (h) in adjacent hemocoel (hc). (F) TEM showing lamina densa layers of basement membrane (bm) covering the basal region of digestive gland cells with mitochondria (m) and vesicles. (G) TEM of basement membrane (bm) separating hemocoel (hc) and abdominal muscle cell (mc). Scale bar (A) $30 \mu \mathrm{m},(\mathbf{B}) 15 \mu \mathrm{m},(\mathbf{C}) 25 \mu \mathrm{m},(\mathbf{D}) 100 \mu \mathrm{m},(\mathbf{E}) 1 \mu \mathrm{m},(\mathbf{F}) 0.5 \mu \mathrm{m},(\mathbf{G}) 0.5 \mu \mathrm{m}$.

Although the entire digestive gland is surrounded by a connective tissue sheath (see Section 3.4), each cylindrical tubule of the digestive gland is encased within a BM (Figure 3C). Approximately every $16.7 \mu \mathrm{m}$ there is a band of contractile cells (1.1-1.4, $\overline{\mathrm{x}}=1.2 \pm 0.2 \mu \mathrm{m}$ wide) oriented around the circumference of each tubule. Additional contractile cells oriented longitudinally subdivide each cylinder into approximately 50-60 ovoid or triangular bulges $(14.3-16.7, \bar{x}=15.0 \pm 2.1 \times 5.1-7.5, \bar{x}=6.2 \pm 1.1 \mu \mathrm{m})$. Between the constrictions, the BM is smooth and appears the same as that shown in Figure 3B. Small 
aggregations of two to five hemocytes are commonly seen attached to the surface especially in the depressions between adjacent bulges and the contractile cells.

Individual abdominal muscle cells appear in SEM as elongate cylinders approximately 50-90 $\mu \mathrm{m}$ in diameter with a wrinkled BM coating their surfaces (Figure 3D). Randomly spaced pores measuring $5.3-10.4,(\bar{x}=7.8 \pm 1.4) \mu \mathrm{m}$ diameter are common, as are individual and small clusters of attached hemocytes.

When examined by TEM, the BMs of these three tissues are similar (Figure 3E-G). The lamina densa in the BM surrounding each cardiac myocyte is a single fuzzy, moderately electron-dense layer composed of fibers ranging between 30-40, and averaging $33 \pm 2 \mathrm{~nm}$ in diameter (Figure 3E). The lamina densa in the BM around each digestive gland tubule forms an incomplete layer of electron-dense bodies (Figure 3F). In the BM of abdominal muscles, the lamina densa consists of two electron-dense layers, one thicker $(20-40, \bar{x}=33 \pm 2 \mathrm{~nm})$ and one thinner layer (approximately $40 \mathrm{~nm}$; Figure 3G). All BMs lie directly against the plasma membrane.

\subsection{Tissues Lined by Connective Tissue Sheaths}

Although individual cardiac myocytes, tubules of the digestive gland, and skeletal muscle cells are encased within BMs, the collection of individual cells and tubules is surrounded by a connective tissue sheath that encases each organ and separates it from a hemal space. The term sheath is used when multiple collagenous layers invest an organ. Similar sheaths were found covering the surface of the dorsal abdominal artery, the foregut, the midgut trunk, and the gonad. All sheaths display a rough, irregular surface facing the hemolymph, clearly shown using SEM. Figure $4 \mathrm{~A}$ shows the irregular surface of the sheath enclosing the heart composed of strands of collagenous fibers (typically 4.4-7.5, $\overline{\mathrm{x}}=5.2 \pm 1.2 \mu \mathrm{m}$ diameter) forming a meshwork weaving around pores and depressions that both range in diameter between $4.5 \mu \mathrm{m}$ and $22.7 \mu \mathrm{m}$. Pores appear as empty channels leading deeper into the sheath whereas depressions may have a bottom shelf. Hemocytes (averaging $6.7 \pm 2.1 \mu \mathrm{m}$ in diameter) are frequently observed on the surface of the outer investing layer of the heart, occasionally in clusters up to 30 cells.

The surface of the sheath covering the collection of digestive gland tubules is wrinkled with a relatively smooth surface between folds (Figure 4B). Pores were small (1.2-4.7, $\bar{x}=2.8 \pm 0.5 \mu \mathrm{m}$ diameter) and rare. Hemocytes were observed on the surface of the sheath and bound to pores. A fortuitous tear in the sheath allows visualization of the constricted BM coating an individual digestive gland tubule lying beneath the sheath (Figure 4B).

The outer surface of the dorsal abdominal artery and midgut trunk are also covered by connective tissue sheaths, which show the greatest degree of surface irregularities (Figure 4C,D); the sheaths are highly folded. The surface of the dorsal abdominal artery has ridges oriented primarily parallel to the long axis of the vessel (Figure 4C). A small vessel is shown branching from the dorsal artery and has the same appearance. The folds on the surface of the midgut trunk appear as overlapping flaps with a width and height ranging between 4-8 and 5-9 $\mu \mathrm{m}$, respectively, with a thickened ridge over the apex and pores, larger than seen in other tissue, up to $35 \mu \mathrm{m}$ in diameter are present (Figure 4D). Fewer hemocytes are seen on the surface of the midgut trunk as compared to the dorsal abdominal artery, but they are always present.

When observed by SEM, the sheath surrounding the gonad lacks the high-profile ridges seen on the dorsal abdominal artery and midgut trunk; the surface shows multiple folds running both along the longitudinal and circumferential axes (Figure 4E). Pores were not observed and individual hemocytes were occasionally present. The sheath covering the foregut (Figure $4 \mathrm{~F}$ ) is morphologically similar to the sheath over the gonad; it is flat with a roughened surface penetrated by numerous small, randomly distributed pores (7.9-23.6 $\mu \mathrm{m}$ in diameter). Hemocytes are common on this surface and are found within many of the holes. 

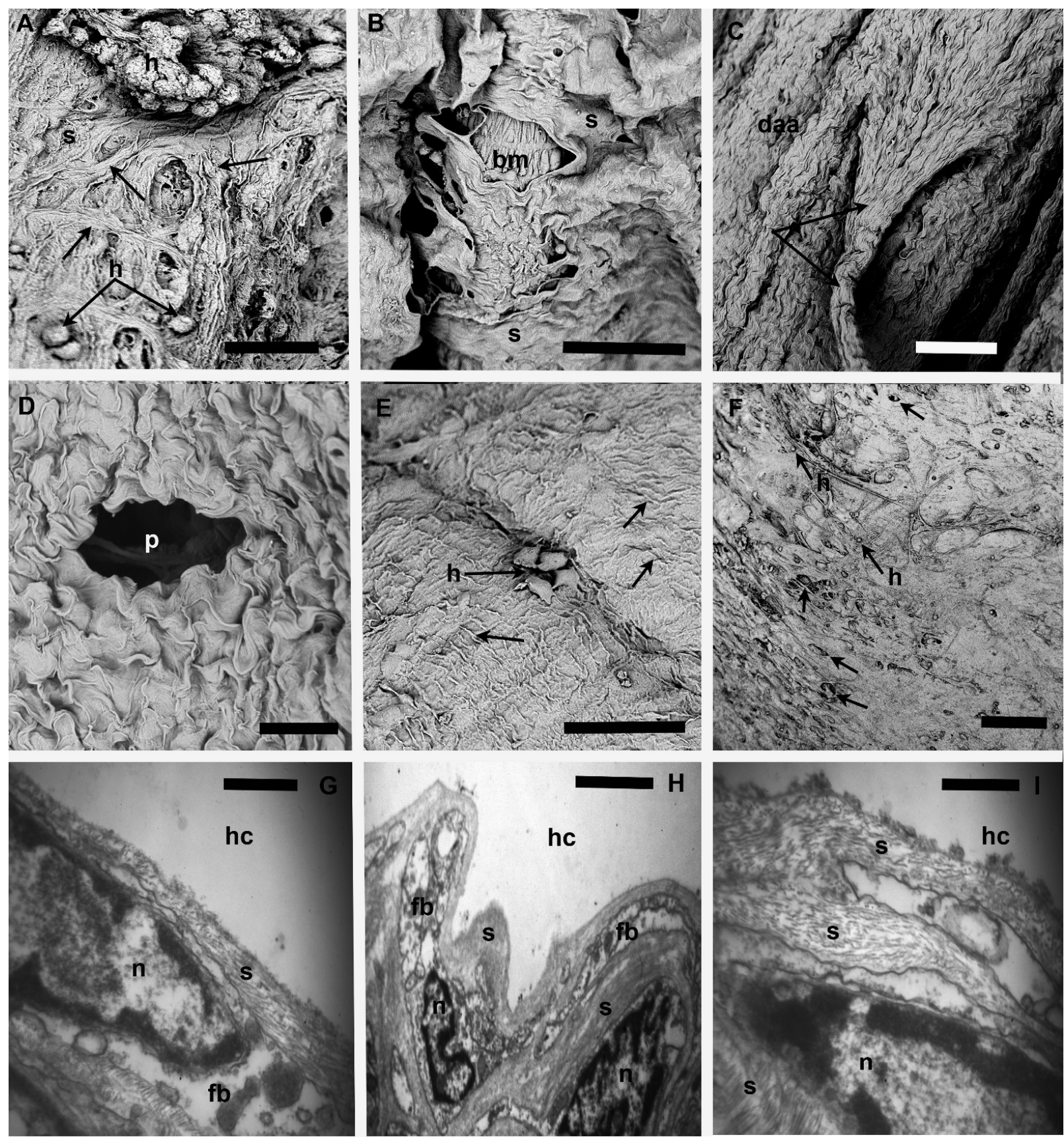

Figure 4. Tissues covered by a connective tissue sheath. (A) SEM of sheath (s) overlying a collection of myocytes composing the heart with tracts of collagen fibers (arrows) forming a weave often around ovoid depressions opening to lower layers of the sheath. Hemocytes (h) are common either individually or in clusters. (B) SEM of connective tissue sheath (s) covering the digestive gland with an artifactual tear providing a look through the sheath at the underlying basement membrane (bm) covering an individual tubule. (C) SEM showing wrinkled surface of outer sheath of connective tissue covering the dorsal abdominal artery (daa) with a smaller vessel (arrows) branching off to one side. (D) SEM showing wrinkled surface of connective tissue sheath covering the midgut trunk with an ovoid pore (p) extending into deeper layers of the gut wall. (E) SEM of acellular sheath of collagenous material covering the outer surface of the gonad with low profile ridges (arrows) and a small cluster of hemocytes (h) in a fold. (F) SEM of surface of foregut covered by a sheath of collagenous material perforated by numerous pores (arrows) opening to deeper layers of the sheath. Bound hemocytes (h) are common. (G) TEM showing collagenous layers (s) separated by a fibroblast-like cell (fb). n, nucleus. (H) TEM showing folder layers of collagenous sheath (s) separating the hemocoel (hc) from a fibroblast-like cell (fb) in the outer layer of the midgut trunk. $\mathrm{n}$, nucleus. (I) TEM showing layers of connective tissue sheaths (s) separating hemocoel (hc) from the nuclear (n) region of fibroblast-like cell. Scale bar (A) $25 \mu \mathrm{m}$, (B) $40 \mu \mathrm{m}$, (C) $60 \mu \mathrm{m}$, (D) $15 \mu \mathrm{m}$, (E) $25 \mu \mathrm{m}$, (F) $30 \mathrm{um}$, (G) $20 \mu \mathrm{m},(\mathbf{H}) 25 \mathrm{um}$, (I) $0.5 \mu \mathrm{m}$. 
Using TEM, the thickness of the investing sheaths is difficult to measure because collagenous layers lining the hemal spaces appear identical to those that merge with the connective tissue of the walls (Figure 4G-I). An intervening, incomplete layer of fibroblastlike cells may or may not be present. Measuring only the collagenous layers between the cells and the hemal spaces suggests the sheath around the gonad was the thinnest $(1.5 \pm 1.2 \mu \mathrm{m})$ and that investing the foregut the thickest $(3.1 \pm 1.4 \mu \mathrm{m})$. All sheaths examined by TEM showed the same morphology; bundles of collagen fibers separated by electron-lucent spaces with a small number of elongate fibroblast-like cells forming incomplete layers. The extensions of these cells may be extremely thin $(0.16 \mu \mathrm{m})$ and often appear empty. The collagen fibers form a weave over the surface of each organ. The diameter of individual fibers ranges from 15.9-21.8, $\bar{x}=20.2 \pm 1.1 \mathrm{~nm}$ in diameter and display a periodicity of approximately $62 \pm 2.4 \mathrm{~nm}$. The nucleus of the fibroblast-like cells has patches of heterochromatin along the inner border of the nuclear membrane, sparse RER is present, and Golgi bodies are rare.

\section{Discussion}

In this study, we describe three distinct types of acellular matrices lining the hemal spaces of the shrimp Sicyonia ingentis. First, the dorsal abdominal artery is lined with a fibrillin-like interna. Second, tissues where an epithelium (such as digestive gland tubules) and individually hemal-bathed cells (such as cardiac myocytes and muscle cells) are separated from the hemal spaces by a thin BM. Third, collections of muscle cells and digestive gland tubules are separated from the hemolymph by sheaths of connective tissue which are also present on the outer surfaces of the arteries, gonad, and gut.

Major crustacean arteries are lined with a fibrillar, non-collagenous material as observed in the ophthalmic artery [17], the dorsal abdominal artery of the shrimp (present study), and in the aorta of the lobster Homarus americanus [34]. The lobster system has been further studied biochemically to characterize the fibrils as the glycoprotein fibrillin previously known from skin and connective tissues in vertebrates [32]. Its elasticity was demonstrated using stress-strain models [32]. Its presence in the arteries may augment hemolymph propulsion initiated by contractions of the heart.

Once hemolymph flows beyond the large arteries into smaller vessels, there is a transition from a lining of fibrillin to a BM [39]. BMs were also found separating individual cardiac myocytes and abdominal muscle fibers from hemal spaces. In the heart, individual cardiac myocytes are encased within BMs and the entire collection of contractile cardiac cells is surrounded by a connective tissue sheath. Likewise, tubules within that digestive gland of the shrimp rest on a BM that is directly bathed by hemolymph, in agreement with a report on the digestive gland in the lobster [40]. In that study, the sheet of connective tissue encasing the collection of tubules was also described as a "typical, fibrous, connective tissue, containing hemal sinuses and a variety of cell types embedded in a collagenous matrix" [40] as we have described the connective tissue sheath in this paper. The gonad in the shrimp and lobster is also composed of epithelial cells separated from the hemal space by an acellular layer, which was originally referred to as a thick BM [48]. However, we found a thicker layer in the shrimp composed of multiple layers of banded collagen fibers and prefer to characterize it as a connective tissue sheath much like the sheath surrounding the dorsal abdominal artery and midgut trunk. Other organs utilizing an investing layer of BM but not examined in this study include the vessels of the Oka organ [14,17], hematopoietic tissues in shrimp [15], and vessels within the compound eyes of a variety of crustaceans [49]. A fourth organ using BMs is the gill where a study on the shrimp Caridina japonica described the gill lamellae being bounded apically by the exoskeleton and basally by a basal lamina lining the vascular lumen [50]. The BMs are the thinnest acellular layers lining hemal spaces, which may allow for the most rapid exchange of nutrients. For example, work on the vertebrate kidney has suggested that negative charges in the BM may or may not be responsible for the passage of proteins entering into the urine [51]. 
The outer surface of several tissues and organs, such as the arteries, the gonad, the gut, and abdominal muscle, as well as the outer covering of the digestive gland and heart, is covered by sheaths bathed in hemolymph. These are composed of multiple layers of collagen fibers containing a few, widely separated fibroblast-like cells. Given the tensile strength of collagen, the sheaths may provide the greatest stability to the enclosed organs, but at what cost to nutrient exchange?

In this study, the distinction between BMs and connective tissue sheaths in shrimp is solely based on morphology, including the positive staining with PAS and the ultrastructural demonstration of an electron-dense lamina densa. The use of these terms and a definitive distinction between BMs and connective tissue sheaths is based on the presumed nature of the contained collagen; type IV is the definitive component of lamina densa and hence BMs and the sheaths are composed of type I [21,44]. The biochemical nature of collagens in arthropods is best known for insects [52]; in crustacea the interest in collagen studies has been primarily on the abdominal muscle in relation to food quality [53]. Type I, IV, and other types of collagen have been identified from both taxa [52-55] but immunolocalization of these proteins seems limited to work in insects [56]. Although collagens, such as type I and type IV, are highly conserved throughout animal evolution [31,57], commercially available, non-crustacean antibodies may not prove effective in verifying different types of collagen lining different tissues in the shrimp.

The demonstration of fibrillin and two types of collagens lining the hemal spaces complicates our understanding of the physiology of blood flow in crustaceans and presumably other invertebrates with an open circulatory system. In vertebrates, blood is confined within vessels lined by an endothelium. Contact of circulating hemocytes with collagen, such as the BM beneath the endothelium, indicates damage to the endothelium and is a trigger for blood clotting [58]. Clearly, neither collagen nor fibrillin are a trigger for blood coagulation in crustaceans [59]. In addition, the irregular surfaces of the connective tissue sheaths must produce a non-laminar flow, which in vertebrates also encourages blood coagulation $[60,61]$.

It is hoped that this morphological study will encourage future studies to address three topics. First, the types of collagen in the layers need to be established. Second, the effect of the different layers on nutrient exchanges should be addressed. Third, what cells are producing these layers? Embedded cells, such as fibroblast-like cells and muscle, may be the source but seem too few and widely dispersed to cover the large surface area of the entire hemal space. It has been suggested, at least in insects [62-67], that these matrices are deposited by the circulating hemocytes, which could also be the evolutionary source of the endothelia seen in closed circulatory systems $[4,68,69]$. If this can be shown for crustaceans, then the role of the hemocytes will be greatly expanded from their primary research focus on innate immune responses and wound healing $[7,10,70]$.

Author Contributions: G.M., R.B.S., S.B.: investigation; G.M.: decisions on methodology, collection and processing of samples, image analysis, and preparation of the manuscript. All authors have read and agreed to the published version of the manuscript.

Funding: This research received no external funding. R.B.S. received support from the Undergraduate Research Center at Occidental College.

Institutional Review Board Statement: Not applicable.

Informed Consent Statement: Not applicable.

Acknowledgments: We wish to thank Jonathan Williams and Dan Pondella of the Vantuna Research Group at Occidental College for catching the shrimp. We also wish to thank the Undergraduate Research Center at Occidental College, for financial assistance to R.B.S.

Conflicts of Interest: The authors declare no conflict of interest. 


\section{References}

1. McGaw, I.J. The decapod crustacean circulatory system: A case that is neither open nor closed. Microsc. Microanal. 2005, 11, 18-36. [CrossRef]

2. Reiber, C.L.; McGaw, I.J. A review of the "open" and "closed" circulatory systems: New terminology for complex invertebrate circulatory systems in light of current findings. Int. J. Zool. 2009, 2009, e301284. [CrossRef]

3. McMahon, B.R. Control of cardiovascular function and its evolution in Crustacea. J. Exp. Biol. 2001, 204, 923-932. [CrossRef] [PubMed]

4. Monahan-Earley, R.; Dvorak, A.M.; Aird, W.C. Evolutionary origins of the blood vascular system and endothelium. J. Thromb. Haemost. 2013, 11, 46-66. [CrossRef] [PubMed]

5. Salt, G. The Cellular Defense Reactions of Insects; Cambridge University Press: Cambridge, UK, 1970. [CrossRef]

6. Rizki, T.M.; Rizki, R.M. The Cellular Defense System of Drosophila Melanogaster. In Insect Ultrastructure; King, R.C., Akai, H., Eds.; Springer: Boston, MA, USA, 1984; Volume 2, pp. 579-604. [CrossRef]

7. Loker, E.S.; Adema, C.M.; Zhang, S.M.; Kepler, T.B. Invertebrate immune systems-Not homogeneous, not simple, not well understood. Immunol. Rev. 2004, 198, 10-24. [CrossRef] [PubMed]

8. Yang, I.A.; Fong, K.M.; Holgate, S.T.; Holloway, J.W. The role of Toll-like receptors and related receptors of the innate immune system in asthma. Curr. Opin. Allergy Clin. Immunol. 2006, 6, 23-28. [CrossRef]

9. Davids, B.J.; Yoshino, T.P. Integrin-like RGD-dependent binding mechanism involved in the spreading response of circulating molluscan phagocytes. Dev. Comp. Immunol. 1998, 22, 39-53. [CrossRef]

10. Holmblad, T.; Söderhäll, K. Cell adhesion molecules and antioxidative enzymes in a crustacean, possible role in immunity. Aquaculture 1999, 172, 111-123. [CrossRef]

11. Plows, L.D.; Cook, R.T.; Davies, A.J.; Walker, A.J. Integrin engagement modulates the phosphorylation of focal adhesion kinase, phagocytosis, and cell spreading in molluscan defense cells. Biochim. Biophys. Acta (BBA) Mol. Cell Res. 2006, 1763, 779-786. [CrossRef]

12. Kawasaki, M.; Delamare-Deboutteville, J.; Dang, C.; Barnes, A.C. Hemiuroid trematode sporocysts are undetected by hemocytes of their intermediate host, the ark cockle Anadara trapezia: Potential role of surface carbohydrates in successful parasitism. Fish Shellfish Immunol. 2013, 35, 1937-1947. [CrossRef]

13. Chen, J.H.; Bayne, C.J. Bivalve mollusc hemocyte behaviors: Characterization of hemocyte aggregation and adhesion and their inhibition in the California Mussel (Mytilus californianus). Biol. Bull. 1995, 188, 255-266. [CrossRef]

14. Oka, M. Studies on Penaeus orientalis Kishinouye-VIII Structure of the newly found lymphoid organ. Bull. Jpn. Soc. Sci. Fisher 1969, 35, 245-250. [CrossRef]

15. Van de Braak, C.B.T.; Botterblom, M.H.A.; Liu, W.; Taverne, N.; van der Knaap, W.P.W.; Rombout, J.H.W.M. The role of the haematopoietic tissue in haemocyte production and maturation in the black tiger shrimp (Penaeus monodon). Fish Shellfish Immunol. 2002, 12, 253-272. [CrossRef] [PubMed]

16. Martin, G.G.; Hose, J.E.; Kim, J.J. Structure of hematopoietic nodules in the ridgeback prawn, Sicyonia ingentis: Light and electron microscopic observations. J. Morphol. 1987, 192, 204. [CrossRef]

17. Martin, G.G.; Hose, J.E.; Corzine, C.J. Morphological comparison of major arteries in the ridgeback prawn, Sicyonia ingentis. J. Morphol. 1989, 200, 175-183. [CrossRef]

18. Yurchenco, P.D.; Schittny, J.C. Molecular architecture of basement membranes. FASEB J. 1990, 4, 1577-1590. [CrossRef]

19. Asem, E.K.; Feng, S.; Stingley-Salazar, S.; Turek, J.; Peter, A.; Robinson, P. Basal lamina of avian ovarian follicle: Influence on morphology of granulosa cells in-vitro. Comp. Biochem. Physiol. Part C Pharmacol. Toxicol. Endocrinol. 2000, 125, 189-201. [CrossRef]

20. LeBleu, V.S.; MacDonald, B.; Kalluri, R. Structure and function of basement membranes. Exp. Biol. Med. 2007, 232, 1121-1129. [CrossRef]

21. Pedersen, K.J. Invited Review: Structure and composition of basement membranes and other basal matrix systems in selected invertebrates. Acta Zool. 1991, 72, 181-201. [CrossRef]

22. Timpl, R.; Dziadek, M. Structure, development, and molecular pathology of basement membranes. Int. Rev. Exp. Pathol. 1986, 29, 1-112. [PubMed]

23. Timpl, R. Structure and biological activity of basement membrane proteins. Eur. J. Biochem. 1989, 180, 487-502. [CrossRef]

24. Fidler, A.L.; Darris, C.E.; Chetyrkin, S.V.; Pedchenko, V.K.; Boudko, S.P.; Brown, K.L.; Jerome, W.G.; Hudson, J.K.; Roka, A.; Hudson, B.G. Collagen IV and basement membrane at the evolutionary dawn of metazoan tissues. eLife 2017, 6, e24176. [CrossRef] [PubMed]

25. Haraida, S.; Nerlich, A.G.; Wiest, I.; Schleicher, E.; Löhrs, U. Distribution of basement membrane components in normal adipose tissue and in benign and malignant tumors of lipomatous origin. Mod. Pathol. 1996, 9, 137-144.

26. Sanes, J.R. The basement membrane/basal lamina of skeletal muscle. J. Biol. Chem. 2003, 278, 12601-12604. [CrossRef]

27. Bruggink, A.H.; van Oosterhout, M.; de Jonge, N.; Cleutjens, J.P.M.; van Wichen, D.F.; van Kuik, J.; Tilanus, M.G.J.; GmeligMeyling, F.H.J.; van den Tweel, J.G.; de Weger, R.A. Type IV collagen degradation in the myocardial basement membrane after unloading of the failing heart by a left ventricular assist device. Lab. Invest. 2007, 87, 1125-1137. [CrossRef]

28. Yang, H.; Borg, T.K.; Wang, Z.; Ma, Z.; Gao, B.Z. Role of the basement membrane in regulation of cardiac electrical properties. Ann. Biomed. Eng. 2014, 42, 1148-1157. [CrossRef] 
29. Grzelkowska-Kowalczyk, K. The Importance of Extracellular Matrix in Skeletal Muscle Development and Function. In Composition and Function of the Extracellular Matrix in the Human Body; IntechOpen: London, UK, 2016; pp. 3-24. [CrossRef]

30. Reggio, S.; Rouault, C.; Poitou, C.; Bichet, J.B.; Prifti, E.; Bouillot, J.L.; Rizkalla, S.; Lacasa, D.; Tordjman, J.; Clèment, K. Increased basement membrane components in adipose tissue during obesity: Links with TGF $\beta$ and metabolic phenotypes. J. Clin. Endocrinol. Metab. 2016, 101, 2578-2587. [CrossRef] [PubMed]

31. Sekiguchi, R.; Yamada, K.M. Basement membranes in development and disease. Curr. Top. Dev. Biol. 2018, $130,143-191$. [CrossRef] [PubMed]

32. Bussiere, C.T.; Wright, G.M.; DeMont, M.E. The mechanical function and structure of aortic microfibrils in the lobster Homarus americanus. Comp. Biochem. Physiol. Part A Mol. Integr. Physiol. 2006, 143, 417-428. [CrossRef]

33. Davison, I.G.; Wright, G.M.; DeMont, M.E. The structure and physical properties of invertebrate and primitive vertebrate arteries. J. Exp. Biol. 1995, 198, 2185-2196. [CrossRef] [PubMed]

34. McConnell, C.J.; Wright, G.M.; DeMont, M.E. The modulus of elasticity of lobster aorta microfibrils. Experientia 1996, 52, 918-921. [CrossRef]

35. Piha-Gossack, A.; Sossin, W.; Reinhardt, D.P. The evolution of extracellular fibrillins and their functional domains. PLoS ONE. 2012, 7, e33560. [CrossRef]

36. Kielty, C.M.; Baldock, C.; Lee, D.; Rock, M.J.; Ashworth, J.L.; Shuttleworth, C.A. Fibrillin: From microfibril assembly to biomechanical function. Philos. Trans. R. Soc. Lond. Ser. B Biol. Sci. 2002, 357, 207-217. [CrossRef]

37. Ramirez, F.; Sakai, L.Y.; Dietz, H.C.; Rifkin, D.B. Fibrillin microfibrils: Multipurpose extracellular networks in organismal physiology. Physiol. Genom. 2004, 19, 151-154. [CrossRef] [PubMed]

38. Jensen, S.A.; Robertson, I.B.; Handford, P.A. Dissecting the fibrillin microfibril: Structural insights into organization and function. Structure 2012, 20, 215-225. [CrossRef]

39. Chan, K.S.; Cavey, M.L.; Wilkens, J.L. Microscopic anatomy of the thin-walled vessels leaving the heart of the lobster Homarus americanus: Anterior lateral arteries. Invertebr. Biol. 2006, 125, 70-82. [CrossRef]

40. Factor, J.R.; Naar, M. The digestive system of the lobster, Homarus americanus: I. Connective tissue of the digestive gland. J. Morphol. 1985, 184, 311-321. [CrossRef] [PubMed]

41. Feng, T.P.; Liu, Y.M. The connective tissue sheath of the nerve as effective diffusion barrier. J. Cell. Comp. Physiol. 1949, 34, 1-16. [CrossRef] [PubMed]

42. Krnjević, K. The connective tissue of the frog sciatic nerve. Q. J. Exp. Physiol. Cogn. Med. Sci. Transl. Integr. 1954, $39,55-72$. [CrossRef] [PubMed]

43. Twarog, B.M.; Roeder, K.D. Properties of the connective tissue sheath of the cockroach abdominal nerve cord. Biol. Bull. 1956, 111, 278-286. [CrossRef]

44. Ashhurst, D.E.; Chapman, J.A. The tissue sheath of the nervous system of Locusta migratoria: An electron microscope study. J. Cell Sci. 1961, 3, 463-467. [CrossRef]

45. Anderson, S.L. Multiple spawning and molt synchrony in a free spawning shrimp (Sicyonia ingentis: Penaeoidea). Biol. Bull. 1985, 168, 377-394. [CrossRef]

46. Humason, G.L. Animal Tissue Techniques, 4th ed.; WH Freeman and Co.: San Francisco, CA, USA, 1979 ; p. 641.

47. Spurr, A.R. A low-viscosity epoxy resin embedding medium for electron microscopy. J. Ultrastruct. Res. 1969, 26, 31-43. [CrossRef]

48. Talbot, P. The ovary of the lobster, Homarus americanus. I. Architecture of the mature ovary. J. Ultrastruct. Res. 1981, 76, 235-248. [CrossRef]

49. Odselius, R.; Elofsson, R. The basement membrane of the insect and crustacean compound eye: Definition, fine structure, and comparative morphology. Cell Tissue Res. 1981, 216, 205-214. [CrossRef]

50. Nakao, T. The fine structure and innervation of gill lamellae in Anodonta. Cell Tissue Res. 1975, 157, 239-254. [CrossRef]

51. Miner, J.H. Glomerular filtration: The charge debate charges ahead. Kidney Int. 2008, 74, 259-261. [CrossRef]

52. Ashhurst, D.E. Integument, Respiration, and Circulation. In Comprehensive Insect Physiology Biochemistry and Pharmacology; Kerkut, G.A., Gilbert, L.I., Eds.; Pergamon Press: Oxford, UK, 1985; Volume 3, pp. 249-287.

53. Sriket, P.; Benjakul, S.; Visessanguan, W.; Kijroongrojana, K. Comparative studies on chemical composition and thermal properties of black tiger shrimp (Penaeus monodon) and white shrimp (Penaeus vannamei) meats. Food Chem. 2007, 103, 1199-1207. [CrossRef]

54. Yoshinaka, R.; Mizuta, S.; Itoh, Y.; Sato, M. Two genetically distinct types of collagen in kuruma prawn Penaeus japonicus. Comp. Biochem. Physiol. Part B Comp. Biochem. 1990, 96, 451-456. [CrossRef]

55. Sivakumar, P.; Suguna, L.; Chandrakasan, G. Molecular species of collagen in the intramuscular connective tissues of the marine crab, Scylla serrata. Comp. Biochem. Physiol. Part B Biochem. Mol. Biol. 2000, 125, 555-562. [CrossRef]

56. Mirre, C.; Le Parco, Y.; Knibiehler, B. Collagen IV is present in the developing CNS during Drosophila neurogenesis. J. Neurosci. Res. 1992, 31, 146-155. [CrossRef] [PubMed]

57. Naba, A.; Clauser, K.R.; Ding, H.; Whittaker, C.A.; Carr, S.A.; Hynes, R.O. The extracellular matrix: Tools and insights for the 'omics' era. Matrix Biol. 2016, 49, 10-24. [CrossRef]

58. Yau, J.W.; Teoh, H.; Verma, S. Endothelial cell control of thrombosis. BMC Cardiovasc. Disord. 2015, 15, 1-11. [CrossRef]

59. Perdomo-Morales, R.; Montero-Alejo, V.; Perera, E. The clotting system in decapod crustaceans: History, current knowledge and what we need to know beyond the models. Fish Shellfish Immunol. 2019, 84, 204-212. [CrossRef] 
60. Zucker, M.B.; Borrelli, J. Platelet clumping produced by connective tissue suspensions and by collagen. Proc. Soc. Exp. Biol. Med. 1962, 109, 779-787. [CrossRef]

61. Gimbrone, M.A.; Anderson, K.R.; Topper, J.N. The critical role of mechanical forces in blood vessel development, physiology and pathology. J. Vasc. Surg. 1999, 29, 1104-1151. [CrossRef]

62. Wigglesworth, V.B. Digestion and Nutrition. In The Principles of Insect Physiology; Springer: Dordrecht, The Netherlands, 1972; pp. 476-552. [CrossRef]

63. Ball, E.E.; de Couet, H.G.; Horn, P.L.; Quinn, J.M.A. Haemocytes secrete basement membrane components in embryonic locusts. Development 1987, 99, 255-259. [CrossRef]

64. Knibiehler, B.; Mirre, C.; Cecchini, J.P.; Le Parco, Y. Haemocytes accumulate collagen transcripts during Drosophila melanogaster metamorphosis. Roux's Arch. Dev. Biol. 1987, 196, 243-247. [CrossRef]

65. Uhrík, B.; Rýdlová, K.; Zacharová, D. The roles of haemocytes during degeneration and regeneration of crayfish muscle fibres. Cell Tissue Res. 1989, 255, 443-449. [CrossRef]

66. Adachi, T.; Tomita, M.; Yoshizato, K. Synthesis of prolyl 4-hydroxylase alpha subunit and type IV collagen in hemocytic granular cells of silkworm, Bombyx mori: Involvement of type IV collagen in self-defense reaction and metamorphosis. Matrix Biol. 2005, 24, 136-154. [CrossRef]

67. Franklin, B.M.; Maroudas, E.; Osborn, J.L. Sine-wave electrical stimulation initiates a voltage-gated potassium channel-dependent soft tissue response characterized by induction of hemocyte recruitment and collagen deposition. Physiol. Rep. 2016, 4, e12832. [CrossRef]

68. Muñoz-Chápuli, R.; Carmona, R.; Guadix, J.A.; Macías, D.; Pérez-Pomares, J.M. The origin of the endothelial cells: An evo-devo approach for the invertebrate/vertebrate transition of the circulatory system. Evol. Dev. 2005, 7, 351-358. [CrossRef]

69. Hartenstein, V.; Mandal, L. The blood/vascular system in a phylogenetic perspective. BioEssays 2006, 28, 1203-1210. [CrossRef]

70. Söderhäll, K.; Cerenius, L. Crustacean immunity. Annu. Rev. Fish Dis. 1992, 2, 3-23. [CrossRef] 